\title{
Student Spiritual Value Through Environmental Science Learning
}

\author{
Henny Johan ${ }^{1 *}$, Afrizal Mayub ${ }^{1}$ and Sipriyadi ${ }^{2}$ \\ ${ }^{1}$ Magister of Science Education Program, FKIP, Universitas Bengkulu, Indonesia \\ ${ }^{2}$ Department of Biology, FMIPA, Universitas Bengkulu, Indonesia \\ *Corresponding author. Email: hennyjohan@unib.ac.id
}

\begin{abstract}
The aim of this research was to explore spiritual awareness on physic environmental learning activity. This research used pre-experimental, experimental, and experimental data analysis. In the pre-experimental stage, the analysis of environmental physics concepts and spiritual attitudes was carried out, and prepared a data collection instrument. The data collected was a questionnaire on students' perceptions regarding the cultivation of spiritual values. At the experimental stage, the implementation of Environmental Physics learning was integrated with the cultivation of spiritual values. After the implementation, the data was collected and data analysis was done quantitatively. In the post-experimental stage, data analysis, data interpretation, reporting and writing of scientific articles were carried out. Based on the research results, it is known that environmental physics content has the potential to impart spiritual value. Based on the results of the questionnaire analysis, it is also known that the insertion of spiritual values in environmental physics content can increase spiritual attitudes related to divine affection. Students can provide examples of exploration of spiritual values in various environmental physics content. It can be concluded that the environmental physics content can be used to instil a spiritual attitude to answer the challenge of divine affection in the $\mathrm{K}-13$ curriculum.
\end{abstract}

Keywords: Spiritual, Physics environmental, Science learning, Awareness.

\section{INTRODUCTION}

Equipping students with thinking skills and instilling a spiritual attitude are two important things in education. Embedding the spiritual values needs to be done in learning science, including learning environmental physics. Learning activity especially physic environmental strongly potential to embed spiritual attitude in learning activities. Teachers must be prepared to answer the challenges of the 2013 Curriculum. Students must have the ability to think at a high level and have a good spiritual attitude. As we know that the youth's morality has decline. The morality is connected to the life includes spiritual aspect. Religious aspect help avoid bad characters such as crime [1]. The content of environmental physics science connected to the various environmental phenomena. Environmental physics concept is also closely related to the daily phenomena. Daily of natural phenomena replicate the God gracious.
Natural phenomena such hydrological cycle process reflect the God gracious. Hydrological cycle process can be seen at Figure 1.

The hydrological cycle process includes many complex natural phenomena such as evaporation, condensation, precipitation.

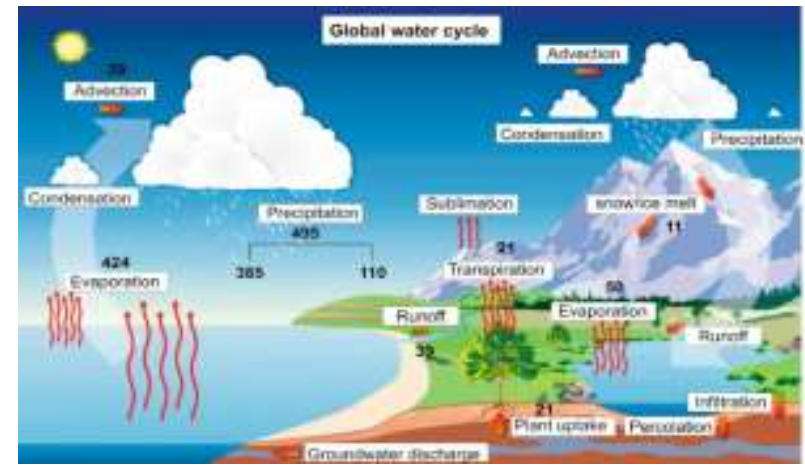

Figure 1. Hydrological cycle process [2] 
Each natural phenomenon which including at the hydrological cycle process reflect the God gracious. It shows the boundaries of the human sanities while inestimable of God. The hydrological cycle maintains the quantity of water on earth. It shows that God is allgranting of grace. Therefore, environmental physics concept is potential to embed spiritual value. D. Rousseau stated that the scopes of axiology and ontology are pertinent to spirituality [4].

Ministerial regulation also stated that one of an important of learning outcome is religious aspect. Religious value must be embed through learning activity [3]. Embedding divine importance is estimated can prevent the moral degradation. This study focus to the embedding spiritual value through the environmental concepts. Presenting facts related to the daily of environmental phenomena can increase awareness of its environmental importance. However, by visualizing the unobservable phenomena at the environment also expected to be used to secure awareness of environmental concerns and show the God gracious. Environmental care needs to be strengthened through the learning of scientific concepts to embed the spiritual value.

\section{METHOD}

\subsection{Research Design}

One group pre-test post-test was conducted in this research. Research flow of this research is available in Fig. 2. The steps of this research include: before learning activity, learning activity, and analysis the research's data. Before learning activities are carried out, the spiritual value was identified in environmental concept. A set of instrument to collect data and instrument for validating the test were constructed. Indicators of Nature of divinity using in the instrument collecting data can be seen at Table 1. In implementation step, 15 postgraduate of science education students were contributed. One group pre-test post-test was conducted in learning activity in physics environmental course to embed spiritual value. Spiritual embedding was done at learning activities of environmental course. After learning process, the data was analysed and the conclusion was constructed.

\subsection{Research Subject}

As many as 15 postgraduate of science education students were involved to this research. These students had never taken physic environmental course before. Convenience sampling was conducted in this research.

\subsection{Instruments for Collecting Data}

The data in this research were collected by a set of Questionnaire. The data collected in this research were the respond related to learning activity and the spiritual awareness. The data collection techniques using posttest. The data from open ended questions was used as supporting data. Sample of open ended question can be seen as: "After learning activities, how can you explain that concepts of environmental make you more belief that God is the infinite assign?"

Table 1. Indicator of questionnaire in this study

\begin{tabular}{|l|l|}
\hline No & \multicolumn{1}{|c|}{ Indicators of Nature of divinity } \\
\hline 1 & realize the nature of God as the creator \\
\hline 2 & realize God's nature as the most gracious \\
\hline 3 & realize God's nature as the most controlling \\
\hline 4 & realize the nature of God as omnipotent \\
\hline 5 & realize the nature of God as omnipotent \\
\hline 6 & realizing God's nature as willful \\
\hline 7 & realize God's nature as omniscient \\
\hline 8 & realize God's nature as all-defining \\
\hline 9 & $\begin{array}{l}\text { realize the nature of God as all taking into account } \\
\text { everything }\end{array}$ \\
\hline 10 & realize God's nature as all-balancing \\
\hline 11 & $\begin{array}{l}\text { realize the nature of God as the most gracious } \\
\text { grantor }\end{array}$ \\
\hline 12 & realize the reason for being wise towards nature \\
\hline 13 & realize the reason for giving thanks to God \\
\hline
\end{tabular}

\section{RESULTS AND DISCUSSION}

Student's spiritual attitudes were found by open ended questions and questionnaire. After learning activity, the data of student's response and student's spiritual awareness were obtained. The physics learning activity was envisioned to explore primarily of students' spiritual awareness connected to awareness of God infinity.

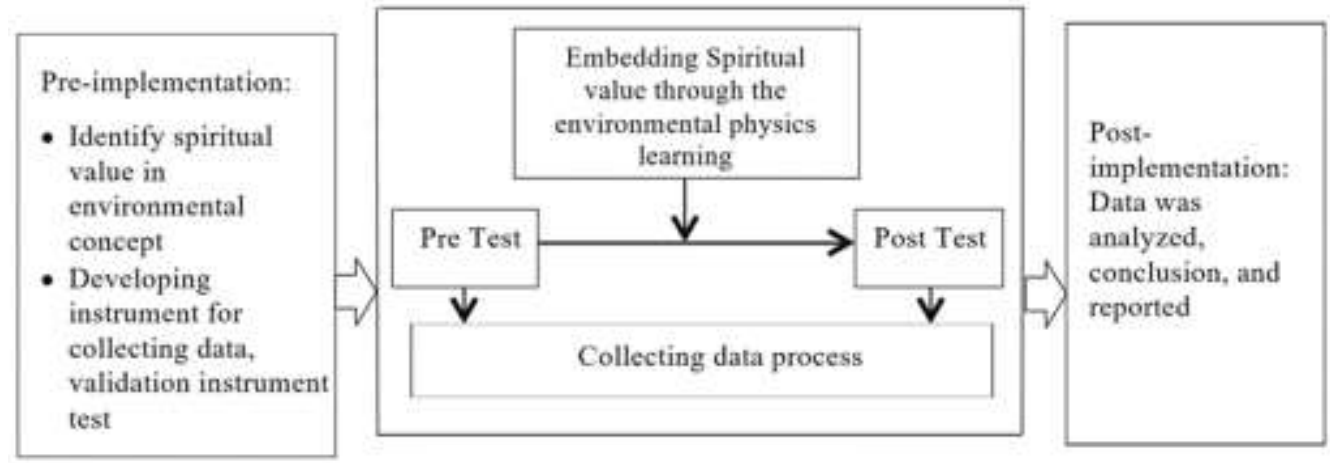

Figure 2. Research design 
Table 2. The data of students' spiritual attitude after physics learning

\begin{tabular}{|c|c|c|c|c|c|c|c|}
\hline \multirow[t]{2}{*}{ No } & \multirow[t]{2}{*}{ Indicators of spiritual attitude } & \multicolumn{2}{|c|}{ Questionaire $1(\%)$} & \multicolumn{4}{|c|}{ Questionaire $2(\%)$} \\
\hline & & Yes & No & SS & $\mathrm{S}$ & TS & STS \\
\hline 1 & $\begin{array}{l}\text { realize the nature of God as the } \\
\text { creator }\end{array}$ & 100 & 0 & 93,3 & 1 & 0 & 0 \\
\hline 2 & $\begin{array}{l}\text { realize God's nature as most } \\
\text { gracious }\end{array}$ & 100 & 0 & 100 & 0 & 0 & 0 \\
\hline 3 & $\begin{array}{l}\text { realize God's nature as the most } \\
\text { controlling }\end{array}$ & 100 & 0 & 93,3 & 1 & 0 & 0 \\
\hline 4 & $\begin{array}{l}\text { realize the nature of God as } \\
\text { omnipotent }\end{array}$ & 100 & 0 & 86,7 & 2 & 0 & 0 \\
\hline 5 & $\begin{array}{l}\text { realize the nature of God as } \\
\text { omnipotent }\end{array}$ & 100 & 0 & 93,3 & 1 & 0 & 0 \\
\hline 6 & realizing God's nature as willful & 100 & 0 & 93,3 & 1 & 0 & 0 \\
\hline 7 & realize God's nature as omniscient & 100 & 0 & 93,3 & 1 & 0 & 0 \\
\hline 8 & realize God's nature as all-defining & 100 & 0 & 100 & 0 & 0 & 0 \\
\hline 9 & $\begin{array}{l}\text { realize the nature of God as all } \\
\text { taking into account everything }\end{array}$ & 100 & 0 & 93,3 & 1 & 0 & 0 \\
\hline 10 & $\begin{array}{l}\text { realize God's nature as all- } \\
\text { balancing }\end{array}$ & 100 & 0 & 86,7 & 2 & 0 & 0 \\
\hline 11 & $\begin{array}{l}\text { realize the nature of God as the } \\
\text { most gracious grantor }\end{array}$ & 100 & 0 & 93,3 & 1 & 0 & 0 \\
\hline 12 & $\begin{array}{l}\text { realize the reason for being wise } \\
\text { towards nature }\end{array}$ & 100 & 0 & 93,3 & 1 & 0 & 0 \\
\hline 14 & $\begin{array}{l}\text { realize the reason for giving thanks } \\
\text { to God }\end{array}$ & 100 & 0 & 93,3 & 1 & 0 & 0 \\
\hline & otal respond $(\%)$ & 100 & 0 & 93.3 & 6,7 & 0 & 0 \\
\hline
\end{tabular}

The data of spiritual awareness is available in Table 2.

Basically, spiritual awareness of students has been good through environmental physic science learning. Based on Table 2, it has been seen that $93.3 \%$ of participant strongly agree that God is gracious. $6.7 \%$ of total participant gave respond agree that that God is gracious. Based on the Table 3 it can be known that no one of the participant disagree that God is gracious. Based on the questionnaire using binary responses, $100 \%$ participant agree that physical environmental phenomena give them awareness that God is gracious. Sample of the respond from participant can be seen at Figure 3.

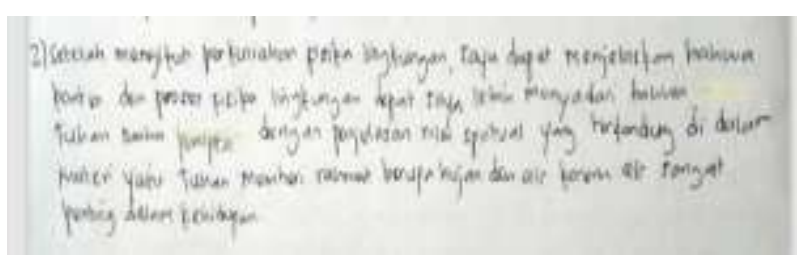

(a)

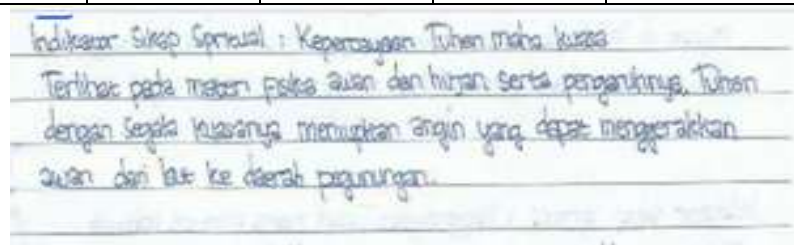

(b)

Figure 3. (a) and (b) respond at open ended question

Figure 3. "I increasingly believe that God is most gracious after take part at the environmental physics learning. The concept of cloud and rain explains that God is most gracious. God brings the wind to blow the clouds. Thus the rain can fall evenly in various places. It is a sign that God is merciful"

Based on Figure 3, participant can explain the relation between the environmental physics concept and the spiritual value related to the divinity. Based on the concept of rain, the participant can understand that rain can fall in various area because the winds blow the rainy clouds. So that why the rain not only fall in the area that close to the ocean. Every place can gave the God bless in the form of rain. Similar to [5], [6], and [7], they stated that spirituality potential to embed by experience 
when they explain the nature phenomena using reasoning or logical thinking. The result also relevant to [8], and [9], they argue that Knowledge of the benefits of various natural phenomena through environmental physics learning can increase students' spiritual awareness. In addition, the results indicate that interactive accomplishments in the classroom by giving chain questions have a positive effect on the spiritual awareness [10]. Equally to [11], they claimed that the manifestation of belief in the worldview occupied by science involved genuine attention to religious roots. God spirituality attitude is strongly potential to block negative influences of globalization [12].

\section{CONCLUSION}

It can be concluded that the environmental physics content can be used to embed a spiritual attitude. Embedding spiritual value in learning activity of environmental physics concept was explored through exploring values of divinity in various phenomena. Most participants strongly agree that God is gracious after take part at environmental physics course. Environmental physics course is related to various natural phenomena that can be connected to statement that God is gracious.

\section{ACKNOWLEDGMENTS}

The authors acknowledge Septi Johan, M.Si and all parties that gave contribution for organizing the data in this study.

\section{REFERENCES}

[1] Anita, Asian Journal of Educational Research \& Technology, 5(1), 80-83, (2015).
[2] Nasa science, Water Cycle, 2020, available online on: https://science.nasa.gov/earthscience/oceano graphy/ocean-earth-system/ocean-water-cycle/

[3] D. Rousseau, Journal of Religion \& Science, 49(2), 476-508, (2014).

[4] Ministerial regulation appendix No. 49 of 2014 on National Standards of Higher Education, (2014).

[5] H Johan et al 2018 J. Phys.: Conf. Ser. 1013 012083

[6] H. Johan, A. Suhandi, A. R. Wulan, Sipriyadi Jurnal Pendidikan Fisika Indonesia 14 (1) .7-17, (2018)

[7] Johan, H., Suhandi, A. Wulan, A.R. Sipriyadi. Journal of Turkish Science Education, 15(1), pp 109-127 (2018)

[8] Johan, H., Suhandi, A., Samsudin, A., Ratna Wulan, A. AIP Conference Proceedings, 2017, 1868, 080004 (2017)

[9] D. Jackson, C. Doyle, H. Capon, and E. Pringle, Journal of Religion, Spirituality \& Aging, 28(4), 281-295, (2016).

[10] Johan et al. Jurnal Pendidikan Fisika Indonesia, Vol 14, No 1 (2018)

[11] A. O. Benz, Journal of Religion \& Science, 52(1), 186-195, (2017).

[12] Brandon K. Burr, J. Brooke Kuns, La Donna Atkins, Anita Glee Bertram, and Kaye Sears, Journal of Religion, Spirituality \& Aging, 27(2-3), 183-200, (2015). 